University of Nebraska - Lincoln

DigitalCommons@University of Nebraska - Lincoln

June 1997

\title{
Political and Economic Analysis of Low-Level Radioactive Waste
}

F. Gregory Hayden

University of Nebraska-Lincoln, ghayden1@unl.edu

Steven R. Bolduc

University of Nebraska-Lincoln, BOLDUC@MNSTATE.EDU

Follow this and additional works at: https://digitalcommons.unl.edu/econfacpub

Part of the Economics Commons

Hayden, F. Gregory and Bolduc, Steven R., "Political and Economic Analysis of Low-Level Radioactive Waste" (1997). Economics Department Faculty Publications. 17.

https://digitalcommons.unl.edu/econfacpub/17

This Article is brought to you for free and open access by the Economics Department at DigitalCommons@University of Nebraska - Lincoln. It has been accepted for inclusion in Economics Department Faculty Publications by an authorized administrator of DigitalCommons@University of Nebraska - Lincoln. 


\title{
Political and Economic Analysis of Low-Level Radioactive Waste
}

\author{
F. Gregory Hayden \\ and \\ Steven R. Bolduc
}

This year's Veblen-Commons Award recipient, Seymour Melman, has warned that the laws and decisions allowing and encouraging the spread of cost-plus contracts have diminished productive capacity, increased production costs, created unearned profits, and weakened democratic institutions ${ }^{1}$ [Melman 1983, 1993]. The concern of this paper is the political organization of the Central Interstate LowLevel Radioactive Waste Compact (CIC) and the cost-plus contract system that it proposes to use in establishing a low-level radioactive waste (LLRW) facility. The current plan is to transport radioactive waste from the LLRW generators in Louisiana, Arkansas, Oklahoma, Kansas, and Nebraska to a disposal facility at the north edge of Nebraska.

\section{Political Goals and Problems of Compacts}

In 1980, Congress passed legislation creating a decentralized system of LLRW compacts. Two basic premises upon which the compact legislation was based have proved incorrect. First, contrary to expectations, the stream of LLRW has continued to decrease since 1980 and is projected to continue to decline. Second, federal compacts are not structured to be successful organizations for this kind of objective.

The authors are Professor and graduate student, respectively, of the Department of Economics, University of Nebraska-Lincoln. F. Gregory Hayden is also a Commissioner on the Central Interstate Low-Level Radioactive Waste Compact Commission. The authors want to thank William C. Snider for his excellent research and computer assistance. This paper was presented at the annual meeting of the Association for Evolutionary Economics, New Orleans, Louisiana, January 46, 1997. 
The growth of federal interstate compacts has been limited in the United States because of the unique circumstances necessary to make them successful. To be successful, all states involved need to share benefits or burdens. All states need to have something to gain or all need to have something to lose. For example, interstate compacts have been vital and effective political organizations for regulating and sharing the benefits of rivers, conservation districts, taxation, education, and for controlling and sharing the costs of disease control and prisoner release. The federally mandated LLRW compacts are inconsistent with a theory of shared benefits and costs. Instead, they are formed so that states in each compact are required to select one state in the compact and force building of the LLRW facility in that state.

This "ganging up" on one state, coupled with the public's growing fear of radiation and public knowledge of past industrial and governmental irresponsibility with regard to nuclear waste [Zinberg 1982, 160], has led to strong efforts to stop, delay, or reform the siting of nuclear facilities [see Lidskog 1994]. The responses vary from the lawsuit brought by Governor Cuomo of New York, to the refusal to allow for federal transfer of land ownership in California, to the current charges of minority discrimination by groups in Texas who claim a site in that state is being considered because the majority of the citizens near the site location are minorities. In other cases, compacts and states have simply required that appropriate research and study be completed before a site is selected. To all of these examples, protest demonstrations and a regular flow of studies by citizen groups can be added. These responses have been met by strong, and occasionally brutal, counter-responses by industrial groups, compact officials, and government agencies. The system has not worked. In 16 years, there has not been a facility approved for construction. Thus, many, including governors and U.S. senators, have suggested that we admit the compact system has not been a success and return the issue to the federal government.

Craig Zeisler, the Nebraska alternative commissioner, has stated a more farreaching political reason why the issue should be returned to the federal government. If a compact system (whereby the federal government requires a group of states to mandate that only one state bear the group's burden) is allowed to succeed, then our nation can expect many similar federally mandated compacts for the unfair allocation of social burdens. Zeisler explained that this would lead to numerous infringements on the sovereign rights of states in the future.

\section{Overview of Problems of Central Interstate Compact}

The expectation for successful LLRW compacts has diminished as the waste stream itself has diminished. The falling waste stream, in conjunction with other institutional trends, creates particular problems with regard to the viability of the CIC project. An integrated overview of these problems can be seen in Figure 1. John 


\section{Figure 1. Incompatible Institutional Trends of Central Interstate Compact}

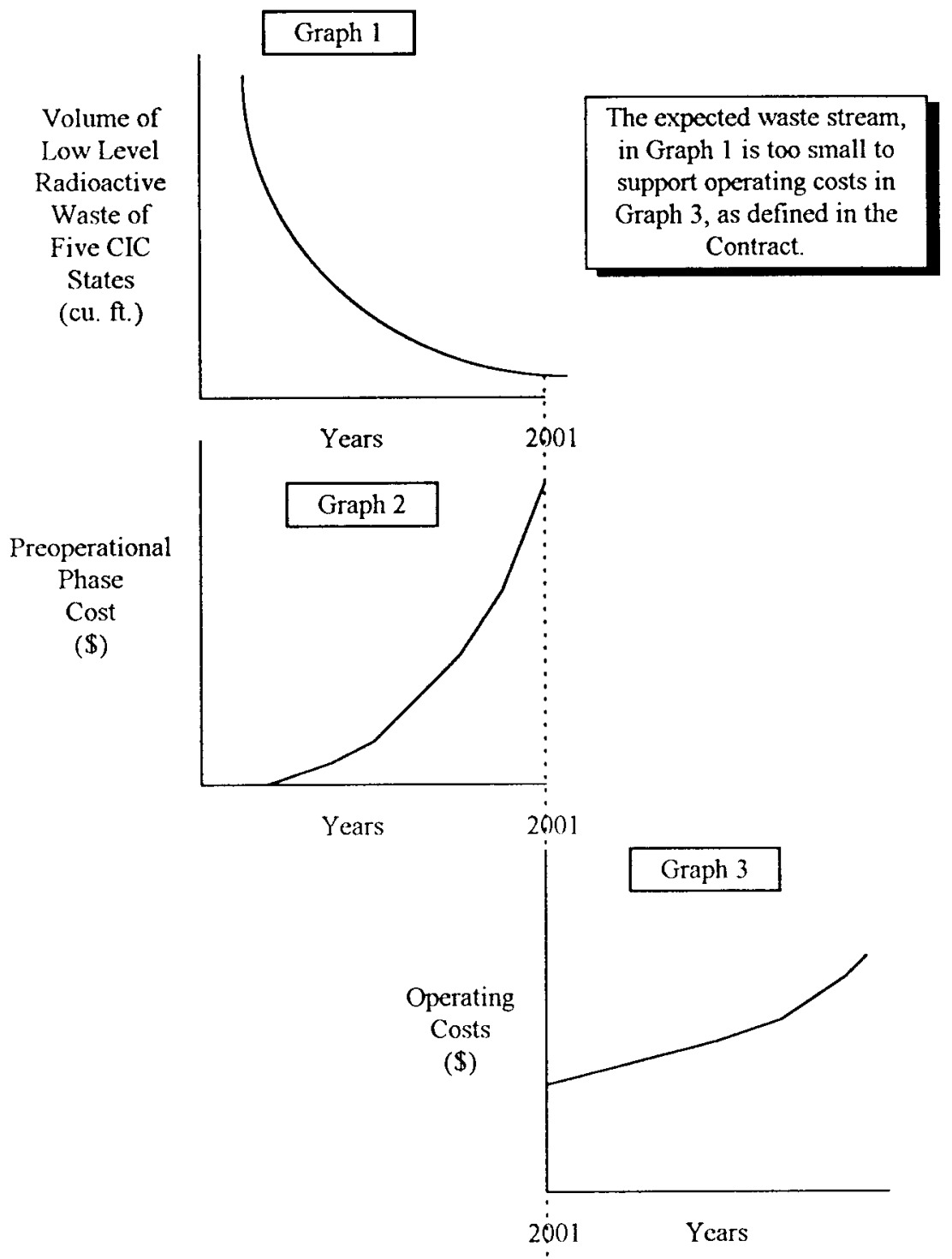


Campbell, writing on nuclear waste, argues that institutional analysis offers a clear advantage because it provides a conceptual vehicle for "teasing out" the important institutional constraints confronting policymakers [Campbell 1987, 29]. The institutional components teased out and compared in Figure 1 show incompatible institutional trends that serve as constraints to the CIC project.

Graph 1 in Figure 1 demonstrates the diminishing LLRW stream in the five-state CIC. It is based on a study completed in August 1996 that found that although the application for permission to build the facility estimated a constant stream of 53,000 cubic feet per year of LLRW over a 30-year life of the project, total LLRW in the five states fell from a high point in 1980 to a level of approximately 12,000 cubic feet in 1995. Due to technological advancements, new cleaning procedures, and better management, projections are that the waste stream will continue to decline [see Hoffman and Hayden 1996]. The statistical projections are confirmed by discussions with nuclear engineers. A national study completed after the CIC study found a similar declining national trend [Fuchs 1996].

Graph 1 reveals conflict with the cost trends shown in Graphs 2 and 3. Cost-plus contracting is causing a rapid escalation of preoperational costs as demonstrated in Graph 2. An estimated beginning date of operation, if the application is approved and construction finalized, is January 2001. Because of the high cost carried into the operational phase, and with the small stream of waste, the cost per unit will be too great to be covered in the early years by the revenues generated by the stream of waste. Total costs will escalate as uncovered costs are carried over from year to year. This is shown in Graph 3.

An additional problem with the high unpaid costs is the financial impact on American Ecology Corporation (AEC), the corporation that has contracted to develop and operate the LLRW facility in Nebraska. The corporation that signed the contract is US Ecology. However, it is a wholly owned subsidiary of AEC, and AEC is designated in the contract. AEC's financial condition ${ }^{2}$ is too fragile [see Hayden 1996] to operate the facility for any period with the kind of financial crisis resulting from the conflicting trends demonstrated in Graphs 1, 2, and 3. In addition, the current financial problems of AEC will worsen if the future expected flow of costs from operating the facility are not forthcoming because the revenues reported today by American Ecology are based, in part, on these expected operating costs. The higher the cost projection by AEC for building and operating the facility, the higher the revenues reported on AEC's 10-K Report to the Security and Exchange Commission. Since the expectation that the excessive costs will ever be paid given the information shown in Figure 1 is not realistic, the financial condition of AEC will worsen. 


\section{Cost-Plus Contracts}

The contracts of concern are the contracts between CIC and AEC and between $\mathrm{CIC}$ and the major electric generators of the five states, here called the "Contract" and "Agreement" respectively.

\section{Contract between CIC and AEC}

The Contract ${ }^{3}$ consists of the original Contract signed June 6, 1987, and three amendments. The cost aspects of the Contract can be translated into the first formula in Table 1. The formula articulates the Contract in conjunction with the practice that has evolved through interpretation by interested agencies that have been in positions of power to reach a consensus and make decisions. ${ }^{4}$

The first formula in Table 1 is for costs in the current prelicensing phase and is set equal to the present value (PV) of the costs paid by CIC to AEC. The majority of the payments go to Bechtel [see CIC Annual Report 1995-96] as the subcontractor to AEC. Before explaining the particulars of the formula, a word of caution: Do not expect the payment formula to operate as usually expected in our economic system. In our system, we expect producing companies to sell stock or borrow funds, pay interest on borrowed funds, buy equipment, and then develop and deliver a product or a constructed facility as defined by the contract. This generally accepted model for development and construction has not been followed with the CIC project. Instead, development costs have been borne by CIC and given to AEC free of interest costs or lease payments. This does not just include operating expenses, but also treats capital equipment as a gift to AEC and Bechtel. In addition, the constructed facility is not to be delivered to $\mathrm{CIC}$, who contracted and paid for it to be built. Ownership during operation remains with AEC. The way cost-plus contracts increase cost becomes apparent by inspecting the particular terms in the formula as follows:

A is the expenses of a sub-subcontractor whose contract with Bechtel does not allow for a cost-plus adder.

$B$ is the expenses of a sub-subcontractor who may add 10 percent to its cost before sending its invoice to Bechtel.

The total of the sub-subcontractor's invoices is increased by a 5 percent costplus adder by Bechtel and sent to AEC, which adds another 5 percent of that total before sending the invoice to $\mathrm{CIC}$.

$\mathrm{C}$ is Bechtel's own operating expenses, exclusive of payroll expenses and capital equipment costs. The expenses, designated as $\mathrm{C}$, are increased by 10 percent before billing AEC. Then AEC increases the 110 percent total by another 5 percent.

$\mathrm{D}$ is Bechtel's home-office payroll expenses for this project. They are increased by about 41.5 percent, and in turn, 78 percent of that total is added. 
$E$ is Bechtel's non-home-office payroll expenses for wages and salaries. It is increased by 41.5 percent, and that total is increased by 42.5 percent.

Then the totals of $\mathrm{D}$ and $\mathrm{E}$, with their adders, as just explained, are increased by a 10 percent cost-plus adder before the invoice is sent to AEC. AEC adds another 5 percent before sending the invoice to CIC.

$\mathrm{F}$ is capital equipment that is bought for the subcontractor, Bechtel, by CIC. Bechtel selects the equipment, adds 10 percent onto the cost of the gift, and sends the bill to AEC. AEC then takes the total 110 percent equipment cost and includes another 5 percent adder of that sum before sending the invoice to CIC.

\section{Table 1. Formulae Expressing Contractual Terms}

A. Cost Terms of Contract between CIC and AEC

$$
\begin{aligned}
\mathrm{PV}= & \{\{\mathrm{A}+[\mathrm{B}(1+.10)]\}\{1+.05\}\}\{1+.05\}+[\mathrm{C}(1+.10)][1+.05] \\
& +\{\{[\mathrm{D}(1+.415)]+[\mathrm{D}(1+.415)][.78]+[\mathrm{E}(1+.415)] \\
& +[\mathrm{E}(1+.415)][.425]\}\{1+.10\}\}\{1+.05\}+[\mathrm{F}(1+.10)][1+.05] \\
& +\mathrm{G}+[\mathrm{H}(1+\mathrm{a})]+\mathrm{DEQ}+[\mathrm{I}(1+.08)]+\{[\mathrm{J}(1+.365)]+[\mathrm{J}(1+.365)][.75] \\
& +[\mathrm{K}(1+.365)]+[\mathrm{K}(1+.365)][.425]\}\{1+.08\}+[\mathrm{L}(1+.08)]+\mathrm{M}
\end{aligned}
$$

B. Financing: Future Value Term of Agreement between CIC and Major Generators

$$
F V=\sum_{j-1987}^{y} P V_{j}(1+r+.065)^{y-j}
$$

FV - future value of financing from major generators to include accrued interest. $j$ year PV was paid; first year being 1987. $y$ - year to which loan is being accumulated. $P V_{j}$ - total value of financing to pay costs in year $\mathrm{j}$. $\mathrm{r}$ - prime interest rate. .065 - interest rate that is added to prime rate.

C. Financing: Future Value Term of Contract between CIC and AEC

$$
F V_{A E C}=\sum_{j-1987}^{y} A E C P V_{j}(1+.20)^{y-j}
$$

$\mathrm{FV}_{\mathrm{AEC}}$ - future value of financing from $\mathrm{AEC}$, to include accrued interest. $j$ - year AECPV was contributed by AEC; first year being 1987. $y$ - year to which loan is being accumulated. AECPV - total value of financing to pay costs in year j. . 20 - interest paid on ACE financing. 
G, H, and DEQ are the expenses incurred by the Nebraska Department of Environmental Quality (DEQ) in its role as licensing and regulating agency. The contractual arrangements are not included on the invoices. Therefore, it is assumed that the sub-subcontractors are both stipulated sum- or unit-cost contracts without costplus adders, represented by $\mathrm{G}$, and cost-plus contracts represented by $\mathrm{H}(1+a)$. The $a$ term represents the unknown percentage adder, if one exists. DEQ represents the costs incurred by its own agency and does not include a cost-plus adder. Neither does DEQ include a cost-plus adder to the costs of G and H. AEC does not add a percentage to the DEQ invoice total hefore submitting it to CIC.

I represents AEC's own operating expenses, exclusive of payroll costs and capital equipment costs. As the contractor, AEC is allowed to include an 8 percent adder to its expenses before submitting them to CIC.

$\mathrm{J}$ is AEC's payments for home-office wages and salaries. $\mathrm{J}$ is increased by about 36.5 percent, and in turn 75 percent of that total is added.

$\mathrm{K}$ is AEC's payments for wages and salaries outside the home office. It is increased by about 36.5 percent, and that total is increased by 42.5 percent.

The totals of $\mathrm{J}$ and $\mathrm{K}$, with their adders, as just explained, are increased by AEC by 8 percent.

$\mathrm{L}$ represents capital equipment that is bought for AEC by CIC. AEC collects, beyond the cost of the equipment, an adder of 8 percent of the cost of the equipment.

As with equipment bought for Bechtel, no lease charge is paid to CIC for using the equipment; AEC owns the equipment so it can be included as an asset on its balance sheet; and AEC can claim the value of the tax deduction for the equipment's depreciation. Then, AEC can apply other inputs, such as its own personnel, to the equipment and send a bill to CIC for the cost of the other inputs, plus an 8 percent adder.

$M$ is the cost of lobbying expenses, upon which cost-plus adders are not allowed.

Since 1987, the total of the Contract costs is about $\$ 80$ million.

\section{Financing Agreement between CIC and Major Generators of Electricity}

There are two sources for financing the costs incurred as a result of the Contract terms defined above. The main financing source is the loan Agreement between CIC and the major generators of electricity in the five states. The major generators agreed to finance the amount of the invoices submitted to CIC from AEC. Thus, the costs are really being financed by the electric ratepayers. The loan receives an accrued interest rate of prime plus 6.5 percent; the total interest rate has reached 17 percent in some years. When the facility begins operation, the loan plus accrued interest will be amortized to be repaid as part of the charges to those depositing 
LLRW at the facility. The financing formula for the loan is defined in part B of Table 1.

FV is the future value of the loan, to include accrued interest. PV, as explained above, is the present value of the costs paid each time invoices are submitted by AEC less what was financed by AEC's financing contribution (see below). Thus, PV continues to grow by the interest rate on the loan. The total value of the loan to pay the Contract costs, plus accrued interest, is currently about $\$ 130$ million.

Financing by $A E C$

In the initial period of the Contract, a small part of the costs-about $\$ 6.2$ millionwas financed by AEC. Since the interest rate on that loan has been 20 percent, the formula for its future value, $F V_{A E C}$, is defined as part $C$ of Table 1 . Its total value currently is about $\$ 22$ million, to include accrued interest plus the original principal of $\$ 6.2$ million.

\section{Concluding Remarks}

The system explained above is the result of unfounded promises, an expensive cost-plus contract, high-interest loan agreements, and a flawed political process. In 1987 , the Contract stated that the cost would be about $\$ 43$ million. To date, about $\$ 80$ million has been paid to contractors, subcontractors, and sub-subcontractors. The total owed to date for borrowed funds and accrued interest is about $\$ 152 \mathrm{mil}-$ lion, and no construction has taken place.

An estimated date for beginning operation is January 1, 2001. By then, the total value on the loans will have increased to about $\$ 350$ million. Those loans plus construction costs, plus construction financing, plus adders, plus miscellaneous cost could reach an estimated $\$ 500$ million by 2001 . That is an estimate of the cost before inclusion of operating costs; inclusion of funding for safety, closure, and postoperation maintenance funds; and of new cost-plus adders. This is the cost package on a facility projected to receive about 5,000 cubic feet of LLRW per year. As demonstrated in Figure 1, the system will not work.

The CIC record is one of civil and political turmoil, a continuous parade of lawsuits, expensive cost-plus adders, reformulations of contracts, cost overruns, an executive director imprisoned, instances of raw intimidation, excessive interest costs on loans, a heavy burden placed on various groups, and nothing built. That is the record of a flawed political process that has ignored institutional realities. This project's record confirms Melman's warnings. We need to return the issue of how to dispose of LLRW to the federal government for a new-and better-solution. 


\section{Notes}

1. Cost-plus contracts use more resources than necessary to reach an industrial production level. Thus, they impose a heavier pollution load on the ecological system and a greater resource taking from the ecological system.

2. Net income of AEC fell from \$7.4 million in 1991 to a negative of \$-48 million in 1995 . AEC's current ratio (current assets divided by current liabilities) fell from 1.5 in 1991 to .6 in 1995 . The quick ratio (current assets convertible into cash divided by current liabilities) fell from 1.48 in 1991 to .59 in 1995 . The debt to equity ratio (long-term debt divided by long-term debt plus total equity) deteriorated from 1.3 percent in 1991 to 56.3 percent in 1995. AEC's net working capital fell from $\$ 7.8$ million in 1991 to a negative of $\$-16.1$ million in 1995.

3. The Contract places the major decisions in the hands of the contractor, AEC. The CIC office has neither research staff nor decision models. Therefore, the commissioners are left in a "rubber stamp" position with regard to plans and work reports of AEC.

4. Because the purpose here is to define the institutional flows as they are processed, some real costs are ignored because they are ignored by the organizations making decisions. Only monetary flows are included in the formula. For example, the lease value of the equipment paid for by CIC and used by Bechtel and AEC is not paid, so it is not included in the formula.

\section{References}

Campbell, John L. "The State and the Nuclear Waste Crisis: An Institutional Analysis of Policy Constraints." Social Problems 34 (February 1987): 18-33.

Central Interstate Low-Level Radioactive Waste Compact (CIC). Annual Report 1995-96. Lincoln, Neb.: CIC Office, 1996.

Fuchs, Ronald L. 1995 State-by-State Assessment of Low-Level Radioactive Wastes Received at Commercial Disposal Sites. DOE/LLW-237. Washington, D.C.: U. S. Department of Energy, 1996.

Hayden, F. Gregory. "Report on the Financial Condition of American Ecology Corporation." Lincoln, Neb.: Office of Nebraska Commissioner, Central Interstate Low-Level Radioactive Waste Compact, March 1996.

Hoffman, D. Jay, and F. Gregory Hayden. "Waste Stream Analysis of the Proposed Low-Level Radioactive Waste Site in Boyd County, Nebraska." Lincoln, Neb.: Office of Nebraska Commissioner, Central Interstate Low-Level Radioactive Waste Compact, Summer 1996.

Lidskog, Rolf. "The Politics of Radwaste Management in Sweden: Civil Society, the Economy and the State." Acta Sociologica 37 (June 1994): 55-74.

Melman, Seymour. Profits Without Production. New York: Knopf. 1983.

. What Else Is There To Do? Neglected Prospects for Major Job Creation in U.S. Manufacturing. Washington, D.C.: National Commission for Economic Conversion and Disarmament, 1993.

Zinberg, Dorothy S. "Public Participation: U.S. and European Perspectives." In The Politics of Nuclear Waste, edited by E. William Colglazier, Jr. New York: Pergamon Press, 1982. 